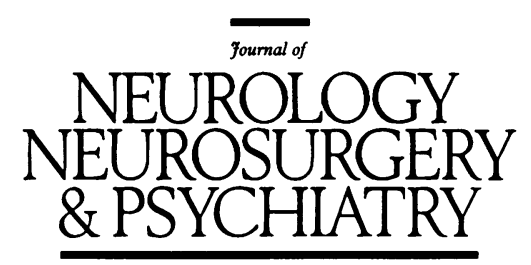

Editorial

\title{
Endorphins: the basis of pleasure?
}

Specific opiate receptors were first described in mammalian nervous systems 19 years ago. ${ }^{1}$ Two varieties of endogenous opiate agonists have been clarified in humans, the enkephalins and the structurally larger endorphins but the term endorphin is often used to encompass both types. Enkephalins are found diffusely in non-cerebellar brain, chiefly in the globus pallidus and spinal cord and outside the CNS in the gastro-intestinal tract, pancreas and adrenal glands. Beta-endorphin is found especially in the pituitary and hypothalamus. At least five separate opioid receptor types are known $(\mu, \delta, \kappa, \varepsilon$ and $\sigma)$. The distribution of these within the CNS varies from one species to another and in most instances it is not possible to relate a single receptor type to one particular function. The best studied compound, morphine, acts by definition on the $\mu$ receptor, whilst ketocyclazocine and dynorphin are the major agonists for the $\kappa$ receptors. However, most opioid agents have mixed receptor activity.

Proposed functions for the endogenous opioid system are numerous but the best evidence relates to effects on analgesia, temperature regulation, appetite and thirst control, sexual behaviour and blood pressure regulation. ${ }^{2}$ If $\beta$-endorphin is given exogenously it has addictive potential similar to opiates. For example, it was found ${ }^{3}$ that rats would work for a response contingent intraventricular injection when receiving relatively low amounts of this neuropeptide. The same phenomenon occurs with metand leu-enkephalin. ${ }^{4}$ Few biological functions have not been related to endorphins at some time, but what is lacking is a cohesive model that gives some "purpose" to these diverse actions. Whilst it has been proposed previously that endorphins represent a "pleasure" system" 5 evidence for this has never been presented on a comprehensive basis. This review examines five varieties of enjoyable human activity and evaluates the role of opiates in each.

\section{Opiate use}

Evidence for opiate use dates back to the Assyrian "poppy" art from 4000BC and to studies of Egyptian, Greek and Persian cultures. The early use of opiates included analgesia but the extent of use for euphoria is not known. It is well documented, ${ }^{6}$ although not widely appreciated, that apart from euphoria, prolonged relaxation and sedation, opiates induce sensations comparable to sexual orgasm. One of the first to describe the orgasm-like quality of opioid administration was John Jones, an eighteenth century English physician describing acute oral ingestion of Tinct Opium ("Laudanum")_- "it has been compared not without good cause to a permanent gentle Degree of that Pleasure which Modesty forbids the name of." "The acute effect of intravenous morphine injections was explicitly described as orgasm-like by one author ${ }^{8}$ who noted pleasurable sensations centred first in the pelvic and pubic area. Another author reported that nearly all of the patients being treated in his clinic for heroin addiction referred to it as an aphrodisiac. ${ }^{9}$ The mechanism by which opioids produce pleasure is not fully understood but it has been suggested that during the brief 30-60 second "rush" that follows intravenous heroin administration there is release of catecholamine both centrally and peripherally. ${ }^{6}$ Paradoxically long term abuse of opioids leads to decline of sexual behaviour.

\section{Love and sex}

There are no studies of endorphin release in humans during coitus but there is evidence from animal studies that sexual stimulation in rats and hamsters may lead to an increase in the activity of endogenous opioid systems. In male rats copulation progressively induces analgesia. ${ }^{1011}$ Vaginal cervical stimulation of female rats has an analgesic effect. $^{12}{ }^{13}$ Plasma $\beta$-endorphin levels taken from male hamsters 30 seconds after their fifth ejaculation were 86 times higher than those of control animals. ${ }^{14}$ In one study $^{11}$ male rats were decapitated after 30 or 120 minutes of copulation but no difference in cerebral opioid content could be found between copulators and control animals at 30 minutes. The midbrain opioid content was significantly reduced in copulators after 120 minutes, which could indicate either inhibition of synthesis or a depletion due to increased turnover or metabolism. Although this report at first sight is contradictory ${ }^{14}$ it must be emphasised that Szechtman's rats had been exposed to repeated painful stimuli and there may be differences between rat and hamster responses. Furthermore, the central activity of $\beta$-endorphin cannot necessarily be inferred from the plasma concentrations. At a more anecdotal level, it is well recognised among migraine sufferers that intercourse can abolish headache.

There is less evidence incriminating endorphins with respect to passionate love and sexual desire. It was speculated ${ }^{15}$ that love brings on a giddy feeling comparable to an amphetamine high and that the crash which follows a breakup is like amphetamine withdrawal. Probably "love addicts" and drug addicts have much in common and the craving for romance is merely the craving for a particular 
kind of "high". 15 The euphoria associated with passionate love could be explained in terms of increased endorphin activity but in the absence of actual measurement this must remain a speculation.

\section{Alcohol}

The enjoyable effects of alcohol consumption need no elaboration but possible mechanisms of action have been elucidated only relatively recently. It was discovered ${ }^{16}$ that opiates and other drugs of abuse mediate their effects through the limbic system, reflecting the reward properties of these drugs. Alcohol like other addictive drugs may exert its reinforcing effect through the same pathway as natural reward transmitters. ${ }^{17}$ It is well known that ethanol and opiates have similar effects, for example, euphoria, development of tolerance and dependence as well as some aspects of withdrawal reactions following chronic exposure.

Although alcohol and opiates are not cross tolerant ${ }^{18}$ there is a notable resemblance between intoxication by each. Ethanol might function indirectly by activation of opiate receptors. ${ }^{19}$ Alcohol administered acutely to animals may be capable of raising cerebral endorphin levels, although not in every region where such peptides can be found. If rats are injected with ethanol $2 \cdot 5 \mathrm{G} / \mathrm{Kg}$ intraperitoneally a $20 \%$ increase in the concentration of metenkephalin in the striatum and $\beta$-endorphin in the hypothalamus may be detected. ${ }^{20}$ In another study similar doses of ethanol induced significant increases of met-enkephalin in rat striatum, midbrain and hypothalamus with a trend towards elevated levels of hypothalamic $\beta$-endorphin levels and reduced hippocampal met-enkephalin. ${ }^{19}$ No significant changes in pituitary $\beta$-endorphin concentrations were recorded. Slightly more ethanol $(3.0 \mathrm{G} / \mathrm{Kg})$ given intra-peritoneally to rats increased $\beta$-endorphin-like immunoreactivity in serum whilst brain levels showed little change, although the $\beta$-endorphin content of the hypothalamus and neurointermediate lobe of pituitary appeared to decrease possibly because of release of opiates into the blood. $^{21}$ Conversely, chronic alcohol exposure produces lowering of endorphin level; 30 days exposure to $20 \%$ ethanol significantly lowered rat striatal and brain-stem met-enkephalin levels whilst $\beta$-endorphin concentration fell in pituitary especially the neuro-hypophysis. ${ }^{1920}$ Hypothalamic levels to both met-enkephalin and $\beta$-endorphin were unaltered. In human studies ${ }^{22}$ a four-fold increase of plasma opioid activity (but not $\beta$-endorphin) was reported in four volunteers following acute ethanol administration. Elevated $\beta$-endorphin (and cortisol) blood levels followed low doses of ethanol by mouth given to healthy nonalcoholic volunteers who had a strong family history of alcoholism. ${ }^{23}$ Naloxone, the opiate antagonist in other human studies, has been shown to reverse alcohol-induced coma $^{24}$ and to prevent the effect of alcohol intoxication. ${ }^{26}$

The major breakdown product of alcohol, acetaldehyde, is thought to combine with catecholamines to produce condensation products known as tetrahydro-isoquinolines (TIQ), for example, tetrahydro-papaverolin (THP) and salsolinol. These substances have marked opiate-like characteristics. ${ }^{27}$ Interestingly benzyl-TIQs are essential intermediates in the biosynthesis of morphine in the poppy plant Papaver Somniferum. ${ }^{27}$ It was suggested ${ }^{28}$ that TIQ formed after ethanol ingestion could function as opiates, furthermore TIQs have been identified in rodent brain after chronic exposure to alcohol. ${ }^{29}$ Rats given intraventricular injection of TIQ increase their alcohol consumption. ${ }^{30}$ Salsolinol is a TIQ formed by condensation of acetaldehyde and dopamine. Human studies $^{31}$ showed higher urinary and CSF salsolinol levels in chronic alcoholics than controls with excess salsolinol in the hippocampus and limbic forebrain, that is, reward areas. However other studies ${ }^{32}$ demonstrated no correlation of salsolinol level in urine following withdrawal or alcohol loading even though aldehyde levels increased in blood. It was suggested that alcoholics might metabolise salsolinol more rapidly or that another unidentified TIQ might be formed. An added complication is that salsolinol is present in normal brain or urine as well as some alcoholic drinks and foodstuffs. ${ }^{33}$ Despite some inconsistencies it remains possible that ethanol and TIQ may act as agonists at enkephalin and endorphin binding sites-particularly the $\delta$ receptor $^{34}$ - where they could displace the natural compounds and induce a false sense of well being.

\section{Food}

Many affluent individuals eat more than their biological needs not for relief of hunger but for pure indulgence; if this becomes excessive it constitutes a pathological disorder-bulimia. According to classical theory there are two major regulatory areas for food intake, both located within the hypothalamus, one in the ventromedial zone (VMH) responsible for satiety and another ventrolaterally (VLH) which initiates feeding. It is significant that VLH is one of the most potent "reward" or "pleasure" centres of the brain. Animals or humans ${ }^{35} 36$ will rapidly learn a response that produces electrical stimulation of this area, furthermore the same electrode that provides pleasure also induces eating. ${ }^{37}$ It now appears more likely that the closely related paraventricular nucleus (PVN) and dorsomedial nuclei (DMN) are responsible for opiate related food regulation. ${ }^{38}$ Many peptides are concerned with food regulation (cholecystokinin and corticotrophin releasing factor both of which inhibit intake) ${ }^{39}$ but opiates could subserve the dual role of promoting ingestion and enjoyment. Morphine, $\beta$-endorphin, met-enkephalamide and especially dynorphin all stimulate eating when microinjected into PVN, whilst naloxone attentuates feeding. ${ }^{40}$ Opiates given parenterally appear to stimulate especially the ingestion of fatty food. ${ }^{41}$ Dynorphin given centrally induces feeding in rats probably by activation of the $\kappa$ receptor within $\mathrm{PVN}^{42}$ whilst $\kappa$-antagonist drugs inhibit feeding, more potently in fact than naloxone. ${ }^{40435}$ There is evidence of a second opioid feeding system within the amygdala which involves $\mu$ receptors, however, this is thought responsible for "foraging" whilst the $\kappa$ system relates to food intake. ${ }^{464}$ In humans opiate antagonists depress food intake over a single meal ${ }^{40}$ as well as the size of a binge in bulimic subjects ${ }^{48}$ but long term use of opiate antagonists are ineffective in this disease. Whilst plasma $\beta$-endorphin levels have been shown to rise in obese subjects, ${ }^{49}$ they are also increased in anorexia nervosa. ${ }^{50}$ Therefore, not all the human and animal data point in favour of a direct role for opiate peptides ${ }^{51}$ but the evidence is strong concerning dynorphin activated $\kappa$ receptors in PVN and that the opioid system is active in humans. $^{39}$

Does hunger stimulate opiate secretion which in turn activates feeding or does feeding per se cause opiate secretion? Probably both mechanisms operate. If endogenous opiate levels increased with feeding this would provide an explanation for much of the pleasure associated with eating. The following gives evidence that opiates could be involved: a) Hypothalamic $\beta$-endorphin secretion is increased when highly palatable food is given to rats ${ }^{52}$ although secretion is also elevated by starvation; b) Patients with bulimia often describe their binging and purging as pleasureable; ${ }^{53}$ c) Stress induced eating can be 
evoked by tail pinch or swimming in laboratory animals and has been found to activate endorphin secretion. ${ }^{5455}$ On suspension of stress-provoked eating in rats a withdrawal syndrome is seen similar to that observed after opiate addiction, ${ }^{54}$ from which it has been suggested that obesity may result from auto-addiction to endogenous opioids. ${ }^{56}$ The obvious drawback with these explanations is that both pain and exercise are suspected to cause increased endorphin release in their own right; d)Enkephalin is found in all areas of human gut, especially the antrum, ${ }^{57}$ both in neurons and open-ended secretory cells. It has been proposed ${ }^{58}$ that in states of obesity the duodenal receptor secretory cells overproduce and release excess enkephalin (or fail to degrade it rapidly enough), and that this would have an effect comparable to morphine; e) It has been reported ${ }^{59}$ that hydrolysates of wheat gluten and $a$-casein contain peptide fragments with opioid activity. Some of these fragments, sometimes called "exorphines", are likely to be produced normally within the stomach, and are protease resistant, and they might therefore reach the brain. ${ }^{60}$

\section{Exercise}

Exercise produces a sense of well being and at least three exercise related phenomena may involve endorphins; the athlete's "high", increased pain tolerance, and addiction to exercise. The runner's "high" is a well recognised phenomenon sometimes compared to the state of euphoria and enthusiasm experienced after opiate consumption. In the rat, endorphin-receptor occupancy increases after acute exercise ${ }^{6162}$ whilst there is elevation of plasma $\beta$ endorphin $^{63-68}$ and leu-enkephalin. ${ }^{69}$ In human studies, mainly in trained runners, $\beta$-endorphin ACTH, prolactin and growth hormone levels all increase. ${ }^{6567} 70$ It appears that high intensity exercise substantially elevates plasma $\beta$-endorphin in $30-60$ seconds $^{71}{ }^{72}$ but moderate exercise for up to one hour may have no effect. ${ }^{73} 74$ There is less agreement concerning endorphin levels and adaptation to chronic exercise. ${ }^{75}$ One study ${ }^{76}$ confirmed an increased $\beta$-endorphin after a marathon run, but found that the levels did not elevate so much in subsequent races, as if some form of adaptation had taken place. Mood elevation is well documented, particularly in depressed patients ${ }^{77-79}$ and because of this, exercise programmes have been used with some success in the treatment of depression. ${ }^{8081}$ Conversely, naloxone administration before exercise abolishes the sense of well being. ${ }^{82}$ There is no doubt that exercise has mood elevating effects but whether this is entirely endorphin-related is uncertain. During exertion there is release of noradrenaline, dopamine, serotonin and prolactin. ${ }^{83-85}$ Corticosteroids are also secreted and could have mood elevating effects presumably independent of endorphin.

Exercise induced analgesia has a well defined relation to opioids. There is strong evidence from animal ${ }^{86}$ and human $^{70}$ studies of an increased pain threshold after exertion. Naloxone reverses the "suppressed" ischaemic pain of exercise. ${ }^{78} 87$ Addiction to exercise may be defined as a pleasurable activity associated with tolerance and withdrawal - then exercise and running would appear to comply. $^{78818889}$ Morgan $^{90}$ described eight cases of running addiction where devotion to jogging assumed a higher priority than commitment to work, family, interpersonal relations and medical advice. Those forced to stop running became depressed, anxious and extremely irritable. It has been suggested that the psychological profile of addicts of either type-narcotic or exercise-have many similarities. $^{78}$ Unfortunately there are no studies of endorphin levels during exercise withdrawal but it is very likely they would fall. Because plasma $\beta$-endorphin levels have universally been shown to increase with exercise, especially running, Steinberg ${ }^{79}$ concludes that exercise has reward value and its effects mimic those of acute or chronic opiate exposure.

Although endorphins are probably major agents in promoting exhilaration other neurotransmitters probably participate in the process-particularly catecholamines such as noradrenaline and dopamine ${ }^{491}$-hence the common observation of heightened sexual sensation when associated with either fear of discovery or amphetamine-like drugs.

The functions of adrenaline and nor-adrenaline were probably viewed as highly complex until Cannon proposed a fundamentally simple "fight and flight" model. By the same token endorphins have diverse functions but this does not detract from what appears to be a major function as "pleasure peptides". Other well established endorphin related functions which are not directly enjoyable such as pain relief, blood pressure regulation and temperature control could be viewed as indirectly promoting or associated with pleasure in much the same way as, for example, adrenaline raises blood pressure and suppresses digestion in assisting fight and flight.

It has been proposed that the prime purpose of human behaviour is to preserve the human genome. ${ }^{92}$ For this it is essential to procreate; hence it is logical that the most enjoyable aspect of life (for most of us!) is heterosexual intercourse. The "drive" for this is maintained probably by the endorphinergic system in the brain. Whilst we protect ourselves from common danger by "fight and flight"hence the adrenergic system - we seek pleasure through the endorphinergic. When we are not indulging in actual procreation, various substituted forms of pleasurable behaviour are sought on a sliding scale of pleasurability, such as, consuming opiate drugs or alcohol; eating beyond satiety; exercise. Interestingly, the higher up the "pleasure scale" the activity is, the greater are the social restrictions. Casual observation of human night-life activity in a large city will demonstrate that in leisure hours most people are seeking ways (both legal and otherwise) of elevating cerebral endorphins. It is therefore probable that other enjoyable activities involve the same endorphinergic system, for example, listening/dancing to music, smoking, religious experience, theatre, gambling and the cinema and are thus fundamental to human survival.

I wish to thank the following for their helpful guidance and comments in preparing this article: Professor TJ Peters, Department of Clinical Biopreparing this article: Professor TJ Peters, Department of Clinical Bio-
chemistry, Kings College Hospital; Professor JE Morley, Division of Geriatric chemistry, Kings College Hospital; Professor JE Morley, Division of Geriatric Medicine, St Louis University Medical Centre, Missouri; Professors AN Davison and G Curzon, Department of Neurochemistry, Institute of NeurolLondon. Mrs M Mortimer kindly provided secretarial support.

Ipswich Hospital, Ipswich, Suffolk

CH HAWKES

1 Pert CB, Snyder SH. Opiate receptor: demonstration in nervous tissue. Science 1973;179:1011-14.

2 Gambert SR, Garthwaite TL, Tate PW. Clinical implications of the endogenous opiates: Pt 1: Physiological. Psychiatric Med 1983;1:93-105. 3 Van Ree JM, Smith DG, Colpert F. Life Sciences 1979;23:495-502.

4 Belluzzi JD, Stein L. Enkephalin may mediate euphoria and drive-reduction reward. Nature 1977;266:556-8.

5 Stein L, Belluzzi JD. Brain endorphins and the sense of well being: A psychobiological hypothesis. Ad Biochem Psychopharmacology 1978;18:299-311.

6 Mirin SM, Meyer E, Mendelson JH, Elingboe J. Opiate use and sexual function. Psychiatr 1980;137:909-15.

7 Jones J. The mysteries of opium revealed. Oxford: Oxford University Press, 1700:265.

8 Kaan H. Moralishe deprivation in ethischer und sexueller sphare bei chronischum morphinismus. Int Klin Rundschan 1891;5:462-509.

9 Becker P. Notiz uber die bedeutung des heroins als anaphrodesiacum. Berl Klin Wochenschr 1903;40:1076-92.

10 Szechtman $H$, Simantov $R$, Hershkowitz M. Effects of naloxone on copulation in rats and the role of endogenous opiate in a spontaneous rewarding behaviour. Soc Neurosci Abstr 1979;5:541. 
11 Szechtman H, Hershkowitz M, Simantov R. Sexual behaviour decreases pain sensitivity and stimulates endogenous opioid in male rats. Eur $\mathcal{F}$ Pharmacol 1981;70:279-85.

12 Komisaruk B, Wallman J. Antinociceptive effects of vaginal stimulation in rats. Neurophysiological and behavioural studies. Brain Res 1977;137:85-107.

13 Komisaruk B. The role of brainstem-spinal systems in genital stimulation: Induced inhibition of sensory and motor responses to noxious stimulation. In: B Sjolund, A Bjorklund, eds. Brainstem control of spinal mechanisms. Amsterdam: Elsevier, 1982:493-508.

14 Murphy MD, Bowie D, Pert C. Copulation elevates plasma $\beta$-endorphin in the hamster. Soc Neurosci Abstr 1979;5:470.

15 Leibowitz MR. The chemistry of love. Boston: Little Brown, 1983.

16 Routtenberg A. The reward system of the brain. Scientific American 1978;239:122-31.

17 Tabakoff B. Neurobiological theories of alcoholism. Washington DC: Addiction Research Foundation, 1983:2-66.

18 Seevers MH, Davis VE, Walsh MJ. Morphine and ethanol physical dependence: a critique of a hypothesis. Science 1970;170:1113-5.

19 Seizinger BR, Boverman K, Maysinger D, Holt V, Herz A Differential effects of acute and chronic ethanol treatment on particular opioid systems in discrete regions of rat brain and pituitary. Pharmacol Biochem Behav 1983;Suppl1:361-9.

20 Schulz R, Wister M, Duka T, Herz A. Acute and chronic ethanol treatment changes endorphin levels in brain and pituitary. Psychopharmacol 1980;68:221-7.

21 Gianoulakis C, Gupta A. Inbred strains of mice with variable sensitivity to ethanol exhibit differences in the content and processing of $\beta$-endorphin. Life Sciences 1986;39:2315-5.

22 Naber D, Soble MG, Pickar D. Ethanol increases opioid activity in plasma of normal volunteers. Pharmacopsychiatry 1981;14:160-1.

23 Gianoulakis $C$. The effect of ethanol on the biosynthesis and regulation of opioid peptides. Experientia 1989;45:428-35.

24 MacKenzie AI. Naloxone in alcohol intoxication. Lancet 1979;i:733-4.

25 Jefferys DB, Flanagan RJ, Volans GN. Reversal of ethanol-induced coma with naloxone (letter). Lancet 1980;i:308-9.

26 Jeffcoate WJ, Herbert M, Cullen MH, Hastings AG, Walder CP. Prevention of effects of alcohol intoxication by naloxone. Lancet 1979;2:1 157-9.

27 Davis VE, Walsh MJ. Alcohol, amines and alkaloids: a possible basis for alcohol addiction. Science 1970;167:1005-7.

28 Blum KL, Hamilton MG, Hirst M, Wallace JE. Putative role of isoquinoline alkaloids in alcoholism: a link to opiates. Alcoholism 1978;2:113-20.

29 Hamilton MG, Blum $K$, Hirst M. Identification of an isoquinole alkaloid after chronic exposure to ethanol. Alcoholism: Clin Exp Res 1978; 2:133-7.

30 Myers RD, Melchior CL. Alcohol drinking: abnormal intake caused by tetrahydropapaveroline (THP) in brain. Science 1977;196:554-6.

31 Sjoquist B, Eriksson A, Windblar B. Salsolinol and catecholamines in human brain and their relation to alcoholism. In: Bloom F, Barchas J, Sandler M, Usdin E, eds. Beta-carbolines and tetrahydroisoquinolines. New York: Alan R Liss. 1983:57-67.

32 Clow A, Topham A, Saunders JB,Murray R, Sandler $M$. The role of salsolinol and alcohol intake and withdrawal. In: Collins NA, ed. Aldehyde adducts in alcohol. New York: Alan R Liss, 1985:101-13.

33 Hirst M, Evans DR, Gowdy CW. Salsolinol in urine of social drinkers. In: Collins MA, ed. Aldehyde adducts in alcoholism. New York: Alan R Liss, 1985:85-100.

34 Hynes MD, Lochner MA, Bemis KG, Hymson DL. Chronic ethanol alters the receptor binding characteristics on the $\delta$ opioid receptor ligand, D-Ala2-D-Leu5 Enkephalin in mouse brain. Life Sciences 1983; 33:2331-7.

35 Valenstein ES. Brain Control. New York: Wiley,1973.

36 Sem-Jacobsen CW. Depth-electrographic stimulation of the human brain and behaviour. Springfield, Ill: CC Thomas, 1968.

37 Margules DL, Olds J. Identical "feeding" and "rewarding" systems in the lateral hypothalamus of rats. Science 1962;135:374-5.

38 Morley JE. The neuro-endocrine control of appetite: the role of the endogenous opiates, cholecystokinin, TRH, gamma-amino butyric-acid and the diazepam receptor. Life Sciences $1980 \mathrm{~b} ; 27: 355-8$

39 Morley JE. Appetite regulation: the role of peptides and hormones. $f$ Endocrinol Invest 1989;12:135-47.

40 Atkinson RL. Opioid regulation of food intake and body weight in humans. Federal Proceedings 1987;46:178-82.

41 Romsos DR, Gosnell BA, Morley JE, Levine AS. Effects of kappa opiate agonists, cholecytokinin and bombesin on intake of diets varying in carbohydrate to fat ratio in rats. $\mathcal{F}$ Nutrition $1987 ; 117: 976-5$.

42 Gosnell BA, Morley JE, Levine AS. Opioid induced feeding: localisation of sensitive brain sites. Brain Res 1986;369:177-84.

43 Morley JE, Levine AS. Dynorphin (1-13) induces spontaneous feeding in rats. Life Sciences 1981;29:1901-3.

$44 \mathrm{Katz}$ RJ. Behavioural effects of dynorphin- a novel opioid neuropeptide. Neuropharmacol 1980;19:801-3.

45 Morley JE, Levine AS, Grace M and Kneip J. Dynorphin (1-13), dopamine and feeding in rats. Pharmacol Biochem Behav 1982;16:701-5.

46 Gosnell BA. Involvement of $\mu$ opioid receptors in the amygdala in the control of feeding. Neuropharmolcol 1988;27:319-26.

47 Kavaliers $M$, Hirst $M$. Slugs and snails and opiate tales: opioids and feeding behaviour in invertebrates. Federal Proceedings 1987;46:168-72.

48 Mitchell JE, Laine DE, Morley JE, Levine AS. Naloxone but no CCK-8 may attenuate binge-eating behaviour in patients with the bulimia syndrome. Biological Psychiatry 1986;21:1399-1406.

49 Facchinetti F, Giovannini C, Barletta C, et al. Hyperendorphinemia in obesity and relationships to affective state. Physiology and Behaviour 1986;36:937-40.

50 Panerai AE, Cavagnini F, Invitti C, Lampertico M, Sacerdote P, Brambilla F. Plasma $\beta$-endorphin and $\beta$-lipoprotein in anorexia nervosa. In: Ferrari E, Brambilla F, eds. Disorders of eating behaviour: a psychoneuroendocrine approach. Oxford: Pergamon Press, 1986:219-27. 5.1 Gosnell BA. Central structures involved in opioid-induced feeding. Federal
Proceedings 1987;46:163-7.

52 Dum J, Gramsch C, Herz A. Activation of hypothalamic $\beta$-endorphin pools by reward induced by highly palatable food. Pharmacology, Biochemistry Behavior 1983;18:443-7.

53 Jonas JM, Gold MS. Naltrexone reverses bulimic symptoms (letter). Lancet 1986;i:807.

54 Morley JE, Levine AS. Stress induced eating is mediated through endogenous opiates. Science 1980;209:1259-61.

55 Vaswani KK, Tejwani GA. Opiate mediated, stress induced increase in the intake of high fat diet. Soc Neurosci Abstr 1982;8:224.

56 Morley JE, Levine AS. The central control of appetite. Lancet $1983 ; \mathbf{i}: 398-401$.

57 Polak JM, Sullivan SN, Buchan AMJ, et al. Endorphins. In: Bloom SR, ed. Gut hormones. Edinburgh, Churchill Livingstone, 1978:501-6.

$58 \mathrm{McCloy}$ RF, McCloy J. Autoaddiction: a hypothesis on hunger and obesity. Am Heart fournal 1980;100:933-4.

59 Zioudrou C, Streaty RA, Klee WA. Opioid peptides derived from food proteins. The exorphines. $f$ Biolog Chemistry 1979;254:2446-9.

60 Kather H, Simon B. Opioid peptides and obesity (letter). Lancet 1979;ii:905.

61 Barta A, Yashpal K, Henry JL. Regional redistribution of $\beta$-endorphin in the rat brain: the effect of stress. Proc Canadian College of Neuropsychopharmacol, 1981 .

62 Pert CB, Bowie DL. Behavioural manipulation of rats causes alteration in opiate receptor occupancy. In: Usdin E, Bunney WE, Kline NS, eds. Endorphins in mental health. New York, Oxford University Press 1979.

63 Appenzeller D, Standefer J, Appenzeller J, et al. Neurology of endurance training: endorphins. Neurology 1980;30:418-9.

64 Bortz WM, Angwin P, Meffird IN, et al. Catecholamines, dopamine and endorphin levels during extreme exercise. New Engl $f$ Med 1981; 305:466-7.

65 Colt WD, Wardlaw SL, Frantz. The effect of running on plasma $\beta$-endorphin. Life Sciences 1981;28:1637-40.

66 Farrell PA, Gates WK, Maaksud MG, et al. Increases in plasma $\beta$-endorphin $/ \beta$-lipoprotein immunoreactivity after treadmill running in humans. $\mathcal{f}$ Applied Physiol 1982;52:1245-9.

67 Fraioli F, Moretti C, Paolucci D, Alicicco F, Crescenzi F, Fortunio G. Physical exercise stimulates marked concomitant increase of $\beta$-endorphin and adrenocorticotrophic hormone (ACTH) in peripheral blood in man. Experimentia 1980;36:987-9.

68 Gambert SR, Garthwaite TL, Pontzen CH, et al. Running elevates plasma $\beta$-endorphin immunoreactivity and ACTH in untrained human subjects. Proc Soc Experi Biol Med 1981;168:1-4.

69 Folkins $\mathrm{CH}$. Effects of physical training on mood. $f$ Clin Physiol 1976; 32:385-8.

70 Janal MN, Colt EWD, Clark WC, Glusman M. Pain sensitivity, mood and plasma endocrine levels in man following long-distance running: effects of naloxone. Pain 1984;19:13-25.

71 Brooks S, Burrin J, Cheetham ME, Hall G, Williams C. The responses of the catecholamines and $\beta$-endorphin to brief maximal exercise in man. European fournal of Applied Physiology and Occupational Physiology 1988; 57:230-4.

72 Rahkila P, Hakala E, Salminen K, Laatikainen T. Responses of plasma endorphins to running exercises in male and female endurance athletes. Medicine and Science in Sports and Exercise 1987;19:451-5.

73 deMeirleir K, Naaktgeboren N, Van Steirteghan A, et al. Beta-endorphin and ACTH levels in peripheral blood during and after aerobic and anaerobic exercise. European $\mathcal{f}$ Applied Physiol 1986;55:5-8.

74 Langenfeld ME, Hart LS, Kao PC. Plasma $\beta$-endorphin responses to one hour bicycling and running at $60 \% \mathrm{VO}_{2}$ max. Medicine $\mathcal{E}$ Science in Sports Eo Exercise 1987;19:83-6.

75 Sforzo GA. Opioids and exercise. An update. Sports Medicine 1988; 7:109-24.

76 Appenzeller O, Appenzeller J, Standefer J, Skipper B, Atkinson R. Opioids and endurance training; longitudinal study. Ann Sports Medicine 1984; 2(1):22-5.

77 Folkins CH, Lynch S, Gardner MM. Psychological fitness as a function of physical fitness. Arch Phys Med Rehab 1972;53:503-8.

78 Pargman D, Baker MC. Running high: enkephalin indicted. $\mathcal{f}$ Drug Issues 1980;3:341-50.

79 Steinberg H, Sykes EA. Introduction to symposium on endorphins and behavioural processes; review of literature on endorphins and exercise. Pharmacology Biochemistry and Behaviour 1985;23:857-62.

80 Folkins CH, Sime WE. Physical fitness training and mental health. Am Psychol 1981;36:373-89.

81 Sachs ML. Running addiction. In: Sacks MH, Sachs ML, eds. The Psychology of Running. Illinois: Human Kinetics 1981:116-26.

82 Markoff RA, Ryan P, Young T. Endorphins and mood changes in long distance running. Med Sci Sports Exerc 1982;14:11-5.

83 Howley ET. The excretion of catecholamines as an index of exercise stress. In: Nagle FJ, Montoye HJ, eds. Exercise in health and disease. Springfield, Ill: Charles C Thomas, 1981 .

84 Bliss EL, Ailion J. Relationship of stress and activity to brain dopamine and homovanillic acid. Life Sciences 1971;10:1161-9.

85 Barchas JO, Freedman DX. Brain amines: response to physiological stress. Biochem Pharmacol 1963;12:1232-5.

86 Shyu BC, Anderson SA, Thoren P. Endorphin mediated increase in pain threshold induced by long-lasting exercise in rats. Life Sciences 1982; 30:833-40

87 Haier RJ, Quaid K, Mills JSC. Naloxone alters pain perception after jogging. Psychiatry Research 1981;5:231-2.

88 Mandell AJ. The second wind. In: Sacks MH, Sachs ML, eds. The psychology of running. Illinois: Human Kinetics 1981:211-33.

89 Soloman EG, Bumpus AK. The running mediation response: an adjunct to psychotherapy. In: Sacks MH, Sachs ML, eds. The psychology of running. Illinois: Human Kinetics, 1981:40-9.

90 Morgan WP. Negative addiction in runners. Phys Sports Med 1979; 7:57-70.

91 Davis WM, Smith SG, Khalsa JH. Noradrenergic role in the selfadministration of morphine or amphetamine. Pharmacol Biochem Behaviour 1975;3:477-84.

92 Dawkins R. The selfish gene. Oxford: Oxford University Press, 1976:224 